\title{
Physical-Hydraulic Quality Indicators of soils with different years of management under Pinot Noir (Vitis vinifera $\mathbf{L}$.)
}

Indicadores de Qualidade Físico-Hidráulica de solos com diferentes anos de manejo sob Pinot Noir (Vitis vinifera $\mathbf{L}$. )

Indicadores de Calidad Físico-Hidráulica de suelos con diferentes años de manejo bajo Pinot Noir

(Vitis vinifera L.)

\begin{abstract}
The present study aimed to evaluate the physical-hydraulic quality of soils with different years of management after planting Vitis vinifera L. cv. Pinot Noir. Areas with 4, 9 and 16 years of cultivation were evaluated, at depths of 0.0 $0.10,0.10-0.20,0.20-0.30,0.30-0.40,0.40-0.50$ and $0.50-0.60 \mathrm{~m}$, in three replicates, in the wheel track (WT), between wheel tracks (BWT) and in the planting row (PR), were analyzed. The physical quality indicators analyzed were bulk density, macroporosity, microporosity, total porosity. Soil water infiltration was also analyzed at these positions, by the method of double concentric rings, both with $30 \mathrm{~cm}$ height, and diameters of $50 \mathrm{~cm}$ in the outer ring and $25 \mathrm{~cm}$ in the inner ring, which were buried $15 \mathrm{~cm}$ deep into the soil and filled with water. Soil management in the different periods of planting resulted in a heterogenous soil compaction in the vine interrows. The position between wheel tracks (BWT) has a higher infiltration rate, regardless of the vineyard management time.
\end{abstract}

Keywords: Vineyard; Soil compaction; Water dynamics.

\section{Resumo}

O presente estudo teve como objetivo avaliar a qualidade físico-hidráulica de solos com diferentes anos de manejo após o plantio de Vitis vinifera L. cv. Pinot Noir. Foram avaliadas áreas com 4, 9 e 16 anos de cultivo, nas profundidades de $0,0-0,10,0,10-0,20,0,20-0,30,0,30-0,40,0,40-0,50$ e $0,50-0,60 \mathrm{~m}$, em três repetições, nas posições de linha da roda $(\mathrm{R})$, entre as trilhas das rodas (ER) e na linha de plantio (LP). Os indicadores de qualidade física analisados foram densidade do solo, macroporosidade, microporosidade, porosidade total. A infiltração de água no solo também foi analisada nessas posições, pelo método dos anéis concêntricos duplos, ambos com $30 \mathrm{~cm}$ de altura e diâmetros de $50 \mathrm{~cm}$ no anel externo e $25 \mathrm{~cm}$ no anel interno, os quais foram enterrados a $15 \mathrm{~cm}$ de profundidade no solo e cheio de água. O manejo do solo nas diferentes épocas de plantio resultou em compactação heterogênea do solo nas entrelinhas. A posição entre rodados (ER) apresenta uma maior taxa de infiltração, independentemente do tempo manejo do vinhedo.

Palavras-chave: Vinhedo; Compactação do solo; Dinâmica da água.

\section{Resumen}

El presente estudio tuvo como objetivo evaluar la calidad físico-hidráulica de suelos con diferentes años de manejo luego de la siembra de Vitis vinifera L. cv. Pinot Noir. Se evaluaron áreas con 4, 9 y 16 años de cultivo a profundidades de 0.0-0.10, 0.10-0.20, 0.20-0.30, 0.30-0.40, 0, 40-0.50 y 0.50-0.60 m, en tres repeticiones, en la línea de rueda. posiciones $(\mathrm{R})$, entre las huellas de las ruedas (ER) y en la línea de siembra (LP). Los indicadores de calidad física analizados fueron densidad del suelo, macroporosidad, microporosidad, porosidad total. También se analizó la 
infiltración de agua en el suelo en estas posiciones, utilizando el método de doble anillo concéntrico, ambos de $30 \mathrm{~cm}$ de altura y $50 \mathrm{~cm}$ de diámetro en el anillo exterior y $25 \mathrm{~cm}$ en el interior, los cuales fueron enterrados a $15 \mathrm{~cm}$ de profundidad en el suelo. y lleno de agua. El manejo del suelo en diferentes épocas de siembra resultó en una compactación heterogénea del suelo entre las líneas. La posición entre ejes montados (ER) tiene una mayor tasa de infiltración, independientemente del tiempo de manejo del viñedo.

Palabras clave: Viñedo; Compactación del suelo; Dinámica del agua.

\section{Introduction}

The concept of soil quality encompasses knowledge on properties and processes relative to the ability of the soil to effectively maintain its production capacity in a sustainable manner (MEA, 2005) and is studied by evaluating indicators that are sensitive to changes caused by use and management (Chaer \& Tótola, 2007). The most studied indicators of soil physical quality are those directly related to soil structure. Resulting from the interaction between particles (clay, silt and sand) and an aggregation agent, such as organic matter, soil structure is the characteristic most affected by anthropic interference (Silva et al., 2017; Santos, et al. 2019; Chaves et al. 2021).

Mechanization, along with other agricultural practices, has contributed to a significant increase in crop yield and reduction in production costs over the last century. However, indiscriminate use may lead to increased density due to alterations in pore shape, which reduces permeability to water, and these indicators are the most studied to evaluate the effects of soil use and management in agricultural areas (Santos et al. 2021).

A soil with ideal structure and medium texture is the one with $0.50 \mathrm{~m}^{3} \mathrm{~m}^{-3}$ of its total volume constituted by pores, of which 0.17 to $0.25 \mathrm{~m}^{3} \mathrm{~m}^{-3}$ must be macropores (important for aeration and water infiltration) and 0.25 to $0.33 \mathrm{~m}^{3} \mathrm{~m}^{-3} \mathrm{must}$ be micropores (responsible for water retention). Thus, the ideal soil bulk density should not exceed $1.8 \mathrm{Mg} \mathrm{m}^{-3}$ (Lima et al., 2007).

Modifications in porosity contribute to altering soil water dynamics. The process of infiltration is influenced by several factors, such as texture, organic matter content, alteration in pore diameter and continuity, and quantity of water in soil (Silva et al., 2014). Medium-textured, well-structured soils may show, in the beginning of the process, water infiltration capacity greater than $30 \mathrm{~mm} \mathrm{~h}^{-1}$, which decreases over time, reaching values lower than $5 \mathrm{~mm} \mathrm{~h}^{-1}$ (Bernardo et. al., 2008).

Several studies related to soil physical quality indicators focus on annual crops. On the other hand, despite the importance for the agricultural sector, few studies report the effect of use and management on perennial crops (Reichert et al., 2007), especially vineyards. Due to the fixed spacing, soil physical quality may vary between sites under tractor traffic and under no traffic (Fidalski et al., 2007; Santos et al. 2014). Given the above, this study aimed to evaluate the physical-hydraulic quality indicators of soils with different years of management after planting Vitis vinifera L. cv. Pinot Noir for the production of sparkling wine.

\section{Methodology and Method}

\section{Characteristics of the studied site}

The study was conducted in a vineyard located in the municipality of Encruzilhada do Sul (30 $31^{\prime} 37^{\prime \prime} \mathrm{S}, 52^{\circ} 31^{\prime} 6^{\prime \prime}$ W), in the Rio Grande do Sul state, Brazil, at $348 \mathrm{~m}$ of altitude. The climate of the region, according to Köppen's climatic classification, is classified as humid subtropical (Cfa) of hot summer, with mean annual temperature and rainfall of $17.4{ }^{\circ} \mathrm{C}$ and $1,533 \mathrm{~mm}$, respectively.

The present study analyzed three areas of the vineyard, cultivated with Vitis vinifera, cv. Pinot Noir, grafted on 1103 Paulsen, cultivated with 4, 9 and 16 years distributed at spacing of $2.5 \mathrm{~m}$ between rows and $1.3 \mathrm{~m}$ between plants, supported by 
a trellis system of planting on Ultisol Xerults (EMBRAPA 2018). In Table 1 presents the textural characteristics of the studied areas, where soils range from silty loam to silty clay loam.

Table 1. Granulometric distribution, textural classification and particle density of the areas with different years of cultivation after grapevine planting.

\begin{tabular}{|c|c|c|c|c|c|}
\hline $\begin{array}{c}\text { Depth } \\
(\mathrm{cm})\end{array}$ & Total Sand & $\begin{array}{r}\text { Silt } \\
\mathrm{g} \mathrm{kg}^{-1}\end{array}$ & $\begin{array}{c}\text { Clay } \\
\end{array}$ & Textural Classification & $\begin{array}{c}\mathrm{Dp} \\
\mathrm{g} \mathrm{cm}^{-3}\end{array}$ \\
\hline & \multicolumn{5}{|c|}{4 years } \\
\hline $0-10$ & 171 & 706 & 123 & Silty loam & 2.50 \\
\hline $10-20$ & 196 & 647 & 157 & Silty loam & 2.49 \\
\hline $20-30$ & 231 & 575 & 193 & Silty loam & 2.53 \\
\hline $30-40$ & 107 & 596 & 297 & Silty clay loam & 2.50 \\
\hline $40-50$ & 109 & 547 & 343 & Silty clay loam & 2.53 \\
\hline $50-60$ & 145 & 418 & 437 & Silty clay & 2.54 \\
\hline \multicolumn{6}{|c|}{9 years } \\
\hline $0-10$ & 139 & 651 & 210 & Silty loam & 2.47 \\
\hline $10-20$ & 147 & 633 & 220 & Silty loam & 2.51 \\
\hline $20-30$ & 104 & 656 & 240 & Silty loam & 2.48 \\
\hline $30-40$ & 125 & 618 & 257 & Silty clay loam & 2.53 \\
\hline $40-50$ & 87 & 516 & 397 & Silty clay & 2.50 \\
\hline $50-60$ & 78 & 462 & 460 & Silty clay & 2.46 \\
\hline \multicolumn{6}{|c|}{16 years } \\
\hline $0-10$ & 202 & 711 & 87 & Silty loam & 2.47 \\
\hline $10-20$ & 226 & 677 & 97 & Silty loam & 2.52 \\
\hline $20-30$ & 213 & 597 & 190 & Silty loam & 2.52 \\
\hline $30-40$ & 253 & 554 & 193 & Silty loam & 2.55 \\
\hline $40-50$ & 234 & 496 & 270 & Clay loam & 2.55 \\
\hline $50-60$ & 102 & 575 & 323 & Silty clay loam & 2.52 \\
\hline
\end{tabular}

$\mathrm{Dp}=$ soil particle density. Source: Authors.

Depending on climatic conditions, there is an average annual traffic of 120 times per interrow, especially from August to December, coinciding with the period of highest requirement of energy for crop development, due to the sprouting, flowering and maturation of the grapes.

\section{Soil sampling}

In each area, $1.5 \mathrm{~m}$ wide x $1.5 \mathrm{~m}$ long x $1.0 \mathrm{~m}$ deep soil pits were opened to collect soil samples at depths of 0.00 $0.10,0.10-0.20,0.20-0.30,0.30-0.40,0.40-0.50$ and $0.50-0.60 \mathrm{~m}$. Disturbed soil samples were collected using a flat shovel in the planting row (PR), in the wheel track (WT) and between wheel tracks (BWT). These samples were homogenized to form one composite sample per depth and were used to determine organic matter content, particle size and particle density.

Undisturbed soil samples were collected with a $102 \mathrm{~cm}^{3}$ volumetric ring in the planting row (PR), in the wheel track (WT) and between wheel tracks (BWT), separately, to evaluate the effect of machine traffic on soil bulk density, macroporosity, microporosity, total porosity and water retention in soil. Water infiltration rate in the field was also evaluated at the same sampling positions.

\section{Analyses of undisturbed samples}

Undisturbed soil samples were subjected to saturation for 48 hours on a tray with water up to two thirds of the ring height to evaluate soil attributes according to the methods described by (Soil methods and analysis manual of the Brazilian Research Corporatin (EMBRAPA, 2017). After the saturation period, the samples were weighed and subjected to $-6 \mathrm{kPa}$ 
suction on a tension table. After the samples stopped losing water, they were removed from the tension table, weighed and dried in an oven at $105^{\circ} \mathrm{C}$ until constant weight.

The difference between the weights of the sample after saturation and after application of $-6 \mathrm{kPa}$ suction on the tension table was used to determine soil macroporosity (Ma) (pores with diameter larger than $0.05 \mathrm{~mm}$ ), whereas the difference between the weights of the sample after $-6 \mathrm{kPa}$ tension and after drying in the oven at $105{ }^{\circ} \mathrm{C}$ was used to determine soil microporosity (Mi) (pores with diameter between 0.05 and $0.0002 \mathrm{~mm}$ ). Total porosity (Tp) was obtained by the sum of these two attributes, $\left(\mathrm{Tp} \mathrm{m}^{3} \mathrm{~m}^{-3}=\mathrm{Ma}-\mathrm{Mi}\right)$. Soil bulk density (Ds) was determined by the relationship between the mass of soil dried in the oven at $105^{\circ} \mathrm{C}$ and the ring volume.

\section{Data statistical analysis}

The experimental design was randomized blocks. Data of soil bulk density, macroporosity, microporosity and total porosity were analyzed as split-split plots, considering the three years of management after vine planting as the main plots $(4,9$ and 16 years), three sampling sites as subplots (between wheel tracks - BWT, in the wheel track - WT and in the planting row PR) and six depths as sub-subplots (0.00-0.10, 0.10-0.20, 0.20-0.30, 0.30-0.40, 0.40-0.50 and 0.50-0.60 m), with 3 replicates, totaling 162 samples. All attributes were subjected to analysis of variance and means were compared by Tukey test at 0.05 significance level. (Who statistical software?).

\section{Evaluation of water infiltration in the field}

Water percolation through the soil was evaluated in situ, by the method of double concentric rings, both with $0.30 \mathrm{~m}$ height, and diameters of $0.50 \mathrm{~m}$ in the outer ring and $0.25 \mathrm{~m}$ in the inner ring, which were buried $15 \mathrm{~cm}$ deep into the soil and filled with water. The variation of water infiltration in the internal ring was measured at intervals of 1, 2, 3, 4, 5, 10, 15, 20, 25, 30, 40, 50, 60, 70, 80 and 90 minutes (Bernardo et al., 2008).

Cumulative soil water infiltration (I) as a function of time was determined based on the model of Kostiakov (1932), described by Libardi (2005) (equation 1):

$$
\mathbf{I}=\mathbf{k} \cdot \mathbf{t}^{\mathrm{n}} \text {. }
$$

Where: $\mathrm{I}=$ cumulative infiltration, in $\mathrm{mm}^{-1} ; \mathrm{k}=$ constant characterizing the type of soil $(\mathrm{k}>0) ; \mathrm{t}=$ time of infiltration, in minutes; $\mathrm{n}=$ constant characterizing the initial soil moisture, dimensionless $(0<\mathrm{n}<1)$.

Soil water infiltration rate, in $\mathrm{mm} \mathrm{h}^{-1}$ (equation 2)

$$
\mathbf{I R}=\mathbf{n . k . t}{ }^{(\mathrm{n}-1)}
$$

Was obtained by deriving the equation of the cumulative water depth with respect to time, as demonstrated in equation 3 ,

$$
\mathbf{I R}=\mathbf{d} \mathbf{d} / \mathbf{d t}
$$

and the arithmetic mean of the last three values of this parameter resulted in the steady-state infiltration rate (SSIR), in $\mathrm{mm} \mathrm{h}^{-1}$.

\section{Results and Discussion}

The results for soil structure, in general, demonstrated a significant statistical difference in macroporosity (Ma), microporosity (Mi), total porosity ( $\mathrm{Tp}$ ) and soil bulk density $(\mathrm{Bd})$ in relation to both the three years of management after planting the vines (4, 9 and 16 years) at the sampling sites (between wheel tracks - BWT, in the wheel track - WT and planting 
row - PR) and the evaluated depths. In all studied sites (years of management and sampling position), there were higher values of Mi, which ranged from 0.25 to $0.75 \mathrm{~m}^{3} \mathrm{~m}^{-3}$, when compared to Ma, which varied between 0.05 and $0.16 \mathrm{~m}^{3} \mathrm{~m}^{-3}(\mathrm{Table} 2)$.

These results were more accentuated in the area with 4 years of management, especially in the tractor wheel track, mainly from $0.30 \mathrm{~m}$ depth, which may be related not only to the vulnerability to soil compaction, as a consequence of the upturning, but also to the increase of clay contents in subsurface layers (Table 1). Consequently, soil bulk density (Bd) ranged

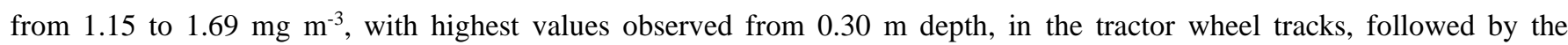
planting row and between wheel tracks.

Based on the values obtained in the soil structure analysis, there was an overall reduction in macroporosity and an increase in microporosity, especially in the tractor wheel tracks and more evident in the area with 4 years of management, which may be related to the shorter time of soil tillage compared to the areas with 9 and 16 years of management. Soil tillage is the activity that most influences the physical attributes, since the application of dynamic loads on the soil by wheels and agricultural implements produces stresses at the soil/tire and soil/implement interfaces in surface and in subsurface, compacting the different soil layers (Vieira \& Klein, 2007).

Table 2. Macroporosity (Ma), microporosity (Mi), total porosity (TP) and bulk density (BD), in the 0.00-0.10 m, 0.10-0.20 m, 0.20-0.30 $\mathrm{m}, 0.30-0.40 \mathrm{~m}, 0.40-0.50 \mathrm{~m}$ and 0.50-0.60 m layers, in the Between the wheel tracks of the tractor (BWT), in the wheel tracks (WT), and planting line (PL) of the areas with 4 years, 9 years and 16 years of management after planting vines.

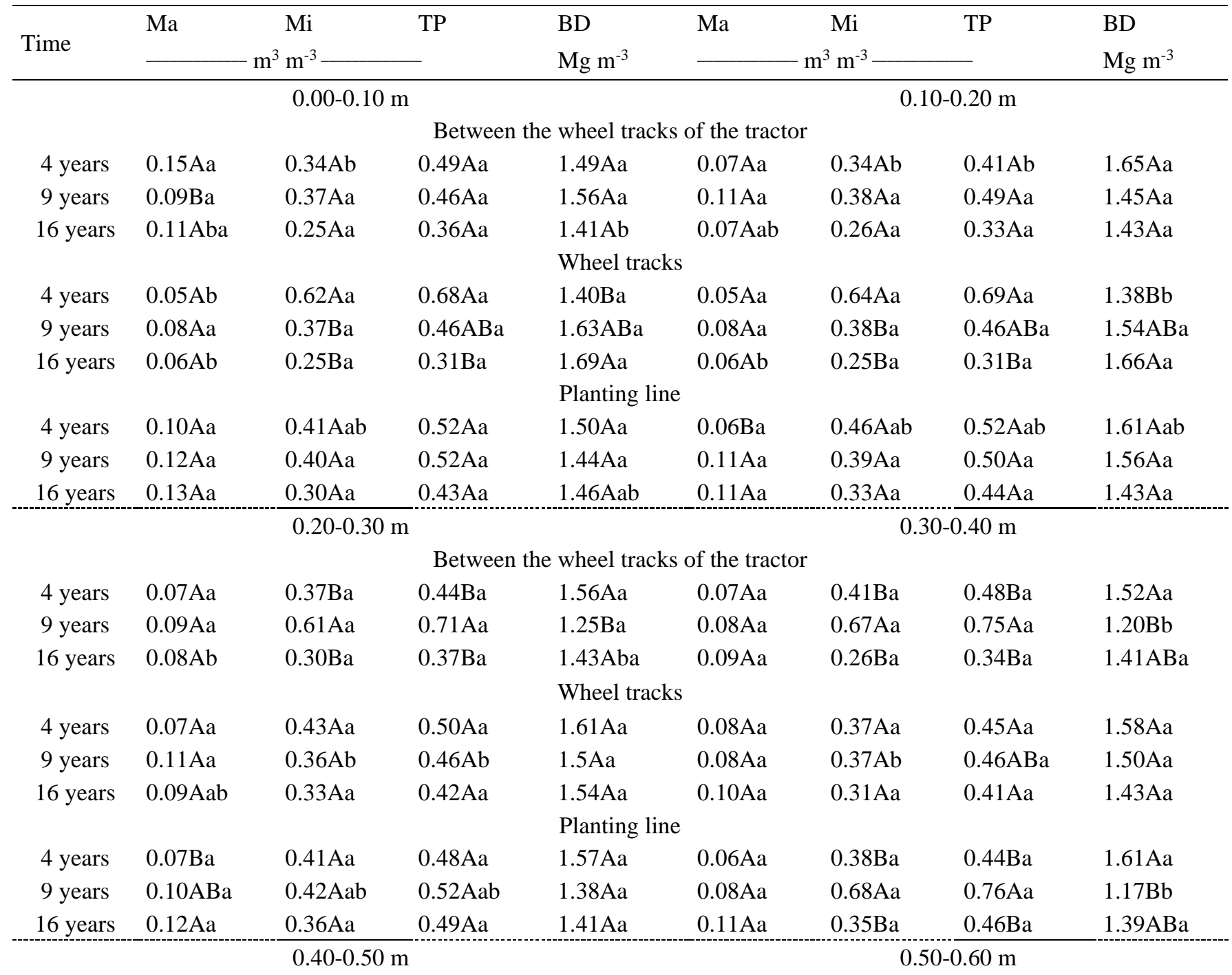




\begin{tabular}{|c|c|c|c|c|c|c|c|c|}
\hline \multicolumn{9}{|c|}{ Between the wheel tracks of the tractor } \\
\hline 4 years & $0.06 \mathrm{Aa}$ & $0.39 \mathrm{Ba}$ & $0.50 \mathrm{Ba}$ & $1.48 \mathrm{Aa}$ & $0.06 \mathrm{Aa}$ & $0.40 \mathrm{Ab}$ & $0.46 \mathrm{Ab}$ & $1.48 \mathrm{Aa}$ \\
\hline 9 years & $0.07 \mathrm{Aa}$ & $0.70 \mathrm{Aa}$ & $0.80 \mathrm{Aa}$ & $1.15 \mathrm{Ba}$ & $0.07 \mathrm{Aa}$ & $0.41 \mathrm{Ab}$ & $0.48 \mathrm{Ab}$ & 1.49Aa \\
\hline 16 years & $0.07 \mathrm{Ab}$ & $0.29 \mathrm{Ba}$ & $0.40 \mathrm{Ba}$ & $1.44 \mathrm{Aa}$ & $0.10 \mathrm{Aa}$ & $0.31 \mathrm{Aa}$ & $0.41 \mathrm{Aa}$ & $1.45 \mathrm{Aa}$ \\
\hline \multicolumn{9}{|c|}{ Wheel tracks } \\
\hline 4 years & $0.06 \mathrm{Aa}$ & $0.40 \mathrm{Aa}$ & $0.46 \mathrm{Aa}$ & $1.56 \mathrm{Aa}$ & $0.06 \mathrm{Aa}$ & $0.39 \mathrm{Ab}$ & $0.46 \mathrm{Ab}$ & $1.52 \mathrm{Aa}$ \\
\hline 9 years & 0.09Aa & $0.41 \mathrm{Ab}$ & $0.49 \mathrm{Ab}$ & $1.41 \mathrm{Aa}$ & 0.07Aa & $0.44 \mathrm{Ab}$ & $0.51 \mathrm{Ab}$ & $1.48 \mathrm{Aa}$ \\
\hline 16 years & $0.11 \mathrm{Ab}$ & $0.31 \mathrm{Aa}$ & $0.42 \mathrm{Aa}$ & $1.38 \mathrm{Aa}$ & $0.06 \mathrm{Aa}$ & $0.4 \mathrm{Ab}$ & $0.46 \mathrm{Aa}$ & $1.44 \mathrm{Aa}$ \\
\hline \multicolumn{9}{|c|}{ Planting line } \\
\hline 4 years & $0.07 \mathrm{Ba}$ & $0.38 \mathrm{Aa}$ & $0.45 \mathrm{Aa}$ & $1.53 \mathrm{Aa}$ & $0.08 \mathrm{Aa}$ & $0.66 \mathrm{Aa}$ & $0.74 \mathrm{Aa}$ & 1.17Aba \\
\hline 9 years & $0.09 \mathrm{Ba}$ & $0.42 \mathrm{Ab}$ & $0.51 \mathrm{Ab}$ & $1.41 \mathrm{Ab}$ & $0.06 \mathrm{Aa}$ & $0.75 \mathrm{Aa}$ & $0.82 \mathrm{Aa}$ & $1.15 \mathrm{Aba}$ \\
\hline 16 years & $0.16 \mathrm{Aa}$ & $0.31 \mathrm{Aa}$ & $0.47 \mathrm{Aa}$ & $1.40 \mathrm{Aa}$ & $0.10 \mathrm{Aa}$ & $0.34 \mathrm{Ba}$ & $0.44 \mathrm{Ba}$ & $1.38 \mathrm{Aa}$ \\
\hline
\end{tabular}

Capital letters = significant statistical difference by the Tukey test at $5 \%$ between the years of cultivation; Lowercase letters $=$ significant statistical difference by the Tukey test at $5 \%$ between sampling sites. Source: Authors.

The values of Mi in the area with 9 years of management were higher at the positions BWT and PR, from $0.40 \mathrm{~m}$, while the area with 16 years of management did not show statistically significant difference. This can be attributed to the fact that, over the years of management, the effect of soil compaction is more pronounced on the subsurface layers, due to the low organic matter content, lower presence of roots and microorganisms capable of favoring aggregation and formation of biopores, as well as the higher contents of clay fractions and finer sand fractions which clog the macropores in subsurface soil layers. Braida et al. (2010) observed that soil susceptibility to compaction can be altered by the accumulation of organic matter, but soil texture and its effects associated with water retention, cohesion and soil bulk density determine its magnitude.

Medium-textured soils should have macroporosity and microporosity varying from 60 to $70 \%$ and from 30 to $40 \%$ of the total porosity, respectively, in the first $30 \mathrm{~cm}$ of depth, which was not observed in this study. In general, at this depth the soil showed macroporosity between 7 and $30 \%$ of total porosity and microporosity from 69 to $63 \%$ of total soil porosity (Reichardt \& Timm, 2004).

Obviously, the reduction of soil porosity in the area under the tractor wheel track, in addition to the presence of fine particles, led to an increase in soil bulk density. Most of the values found are above $1.40 \mathrm{Mg} \mathrm{m}^{-3}$, which is considered critical for good crop development in the first $0.30 \mathrm{~m}$ of depth in a medium-textured soil (Reichert et al., 2003). Similar pattern was found at different sampling positions in medium-textured soils in the interrows of vineyards in Santa Catarina (Valois et al., 2014), and in other perennial crops, such as coffee (Gontijo et al., 2008) and citrus (Santos et al., 2014), subjected to intense machine traffic, in which the reduction of porosity resulted in an increase in soil bulk density.

According to Dalla Rosa (2009), this alteration in soil structure causes reduction of aeration and water infiltration, due to the reduction of macroporosity. On the other hand, the increase in microporosity favors the retention of the small volume of water that percolates through the soil profile. However, in some cases, it does not mean that this water is necessarily available to plants, because there are situations in which these pores undergo a significant reduction of diameter and water may remain retained with very high energy, thus being unavailable to plants (Toigo 2010).

The fitting equation used had a high correlation coefficient, with $\mathrm{R}^{2}$ between 0.50 and 0.77 for $f$ and $\mathrm{R}^{2}$ between 0.86 and 0.99 for $I$, which makes the model proposed by Kostiakov (1932) adequate to explain the variation of these parameters as a function of time (Table 3). These results confirm those found by Cunha et al. (2009), who compared the Kostiakov model with others applicable to the fitting of IR and I curves. 
Table 3. Water infiltration rate (IR), accumulated water infiltration (I) and velocity of steady-state infiltration rate (SSIR) of water in the soil, in area with 4 years, 9 years and 16 years of management after planting vines.

\begin{tabular}{|c|c|c|c|c|c|}
\hline \multirow{2}{*}{ Time } & \multicolumn{2}{|c|}{ Water infiltration rate } & \multicolumn{2}{|c|}{ Accumulated water infiltration } & \multirow{2}{*}{$\begin{array}{c}\text { SSIR } \\
\mathrm{mm} \mathrm{h}^{-1}\end{array}$} \\
\hline & Equation & $\mathrm{R}^{2}$ & Equation & $\mathrm{R}^{2}$ & \\
\hline \multicolumn{6}{|c|}{ Between the wheel tracks of the tractor } \\
\hline 4 years & $I R=142.81 \mathrm{t}^{-0.313}$ & 0.68 & $I=290.02 \mathrm{t}^{0.453}$ & 0.99 & 33.58 \\
\hline 9 years & $I R=120.69 \mathrm{t}^{-0.192}$ & 0.63 & $I=153.58 \mathrm{t}^{0.557}$ & 0.97 & 42.81 \\
\hline 16 years & $I R=50.457 \mathrm{t}^{-0.215}$ & 0.60 & $I=41.787 \mathrm{t}^{0.613}$ & 0.97 & 17.47 \\
\hline \multicolumn{6}{|c|}{ Wheel tracks } \\
\hline 4 years & $I R=4.6148 \mathrm{t}^{-0.382}$ & 0.50 & $I=2.0441 \mathrm{t}^{0.599}$ & 0.86 & 3.67 \\
\hline 9 years & $I R=22.152 \mathrm{t}^{-0.476}$ & 0.64 & $I=37.638 \mathrm{t}^{0.302}$ & 0.97 & 2.53 \\
\hline 16 years & $I R=11.919 \mathrm{t}^{-0.399}$ & 0.63 & $I=2.1574 \mathrm{t}^{0.672}$ & 0.96 & 1.60 \\
\hline \multicolumn{6}{|c|}{ Planting line } \\
\hline 4 years & $I R=49.956 \mathrm{t}^{-0.270}$ & 0.76 & $I=5.0300 \mathrm{t}^{0.388}$ & 0.94 & 15.67 \\
\hline 9 years & $I R=58.630 \mathrm{t}^{-0.256}$ & 0.77 & $I=106.76 \mathrm{t}^{0.361}$ & 0.96 & 18.47 \\
\hline 16 years & $I R=25.394 \mathrm{t}^{-0.310}$ & 0.65 & $I=47.302 \mathrm{t}^{0.337}$ & 0.93 & 6.40 \\
\hline
\end{tabular}

Classification of steady-state infiltration rate in soil: very tall (SSIR > $\left.30 \mathrm{~mm} \mathrm{~h}^{-1}\right)$; tal $\left(15 \mathrm{~mm} \mathrm{~h}^{-1}>\mathrm{SSIR}_{30} \mathrm{~mm} \mathrm{~h}^{-1}\right)$; medium $\left(5 \mathrm{~mm} \mathrm{~h}^{-1}>\right.$ SSIR $<15 \mathrm{~mm} \mathrm{~h}^{-1}$ ) and low (SSIR $<5 \mathrm{~mm} \mathrm{~h}^{-1}$ ) (Bernardo et al., 2008). Source: Authors.

The steady-state infiltration rate (SSIR) varied in relation to both the years of management after planting the seedlings and the sampling positions, with values varying from 1.60 to $42.81 \mathrm{~mm} \mathrm{~h}^{-1}$ (Table 2). At the site between wheel tracks, SSIR ranged from very high, in the areas with 4 and 9 years of management, to high, in the area with 16 years of management, while in the planting row the SSIR was high in the areas with 4 and 9 years and medium in the area with 16 years of management.

These results corroborate those found in other experiments involving the analysis of water infiltration rate in soils with different textural classes and different managements, in which higher values were observed when the soil was dry, decreasing with the increase of the hydraulic gradient until reaching a constant value (Gondim et al., 2010; Bono et al., 2012), consequently leading to an increase in the cumulative soil water infiltration $(I)$, which at the end of this experiment showed values between 140 and $1700 \mathrm{~mm}$. This is due to the fact that, in addition to management and texture, water dynamics is directly related to the water content present in the pore space of the soil.

The test of soil water infiltration demonstrated that, in general, the highest values of both infiltration rate $(f)$ and cumulative infiltration $(I)$ were observed between the wheel tracks, followed by the planting row and the wheel tracks, with the lowest values observed in the area with 16 years of management. Consequently, while the steady-state infiltration rate in the area with 9 years of management varied between 2.53 and $42.81 \mathrm{~mm} \mathrm{~h}^{-1}$, in the areas with 4 and 16 years of management these values were between 3.67 and $33.58 \mathrm{~mm} \mathrm{~h}^{-1}$ and between 1.60 and $17.47 \mathrm{~mm} \mathrm{~h}^{-1}$, respectively (Figure 1). 
Figure 1. Water infiltration rate and accumulated water infiltration in areas with 4 years, 9 years and 16 years of management after planting vines. Between the wheel tracks of the tractor (BWT), in the wheel tracks (WT), and planting row (PR).
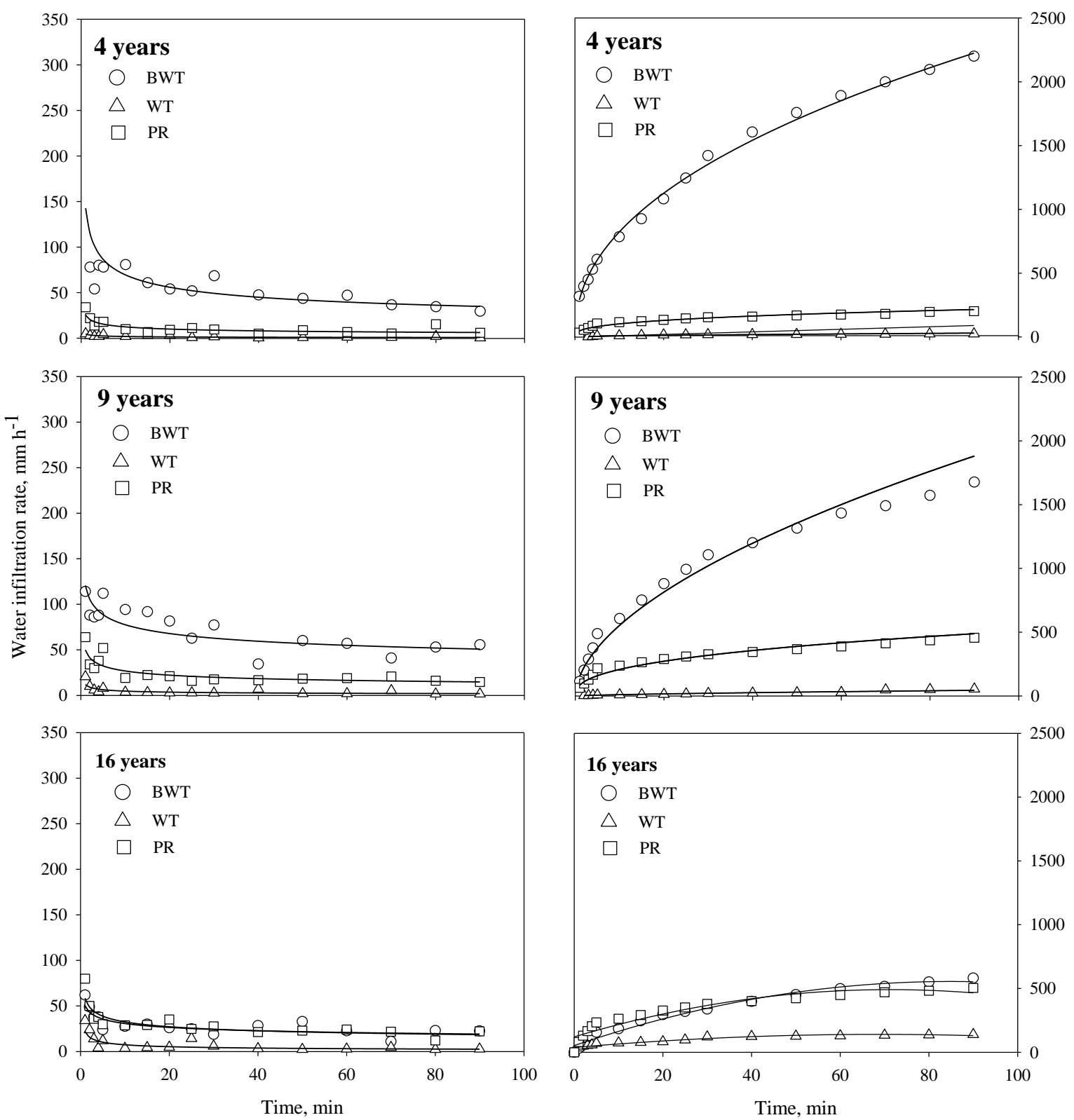

Source: Authors.

By analyzing the areas with three times of management after planting the vines and the sampling positions, it was possible to observe the highest values in the areas with 4 and 9 years, especially between the wheel tracks (BWT), followed by the planting row (PR) and the wheel tracks (WT). These patterns are contrary to those found by Santos et al. (2014) in a citrus orchard grown on a sandy Argissolo (Ultisol), in which the highest values of IR and I were found in PR (planting row), followed by BWT (between wheel tracks) and WT (wheel track).

This can be explained by the fact that, unlike what occurs in other perennial crops, in vineyards the planting row is very close to where the tractor wheels pass, dissipating their pressure on soil both vertically and horizontally to the closest site to the source of the compaction (Santos, et. al., 2014). In intensely cultivated soils, the occurrence of compacted layers reduces the volume of macropores, responsible for water infiltration and redistribution (Bertol et al., 2001), and the low infiltration 
occurs in a more pronounced manner at the beginning of the infiltration, decreasing exponentially over time (Santos, et al., 2014).

On the other hand, the compaction caused by the tractor wheels in their tracks resulted in a low SSIR for all years of management after planting the seedlings. According to Cunha et al. (2009), the phenomenon of compaction hinders water penetration, decreasing the SSIR of the soil.

\section{Conclusion}

Soil management in the different periods of planting resulted in a heterogenous soil compaction in the vine interrows, with highest values observed in the tractor wheel tracks (WT), followed by the planting row (PR) and between wheel tracks (BWT). Such alteration in soil structure contributed to poor water infiltration in the most compacted sites (WT and PR).

\section{Agradecimentos}

To colleagues at the Federal University of Rio Grande do Sul for their contributions to this study and to the funding agencies CAPES and CNPq for financial assistance.

\section{References}

Bernardo, S., Soares A. A., \& Mantovani. (2008). Manual de irrigação. (8a ed.) 625, UFV.

Bertol I., Beutler J. F., Leite D. \& Batistela O. 2001. Propriedades físicas de um Cambissolo Húmico afetadas pelo tipo de manejo do solo. Scientia Agricola, 58, 555-560. http://dx.doi.org/10.1590/S0103-90162001000300018.

Bono, J. A. M., Macedo, M. C. M., Tormena, C. A., Nanni, M. R., Gomes, E. P. \& Müller, M. M. L. (2012). Infiltração de água no solo em um Latossolo vermelho da região sudoeste dos cerrados com diferentes sistemas de uso e manejo. Revista Brasileira de Ciência do Solo, 32, $1845-1853$. http://dx.doi.org/10.1590/S0100-06832012000600019.

Braida, J. A., Reichert, J. M., Reinert, D. J., \& Veiga, M. da. (2010). Teor de carbono orgânico e a susceptibilidade à compactação de um Nitossolo e Argissolo. Revista Brasileira de Engenharia Agrícola e Ambiental, 14, 131-139. http://dx.doi.org/10.1590/S1415-43662010000200003.

Chaer, G.M. \& Tótola, M.R. (2007). Impacto do manejo de resíduos orgânicos durante a reforma plantios eucalipto sobre indicadores qualidade solo. Revista Brasileira de Ciência do Solo, 31, 1381-1396. http://dx.doi.org/10.1590/S0100-06832007000600016.

Chaves, E., Santos, C. V., Bertolazi, V. T., INDA Junior, A. V., Levien, R. (2021). Changes in typical Acrisol under vineyard in southern Brazil . Research, Society and Development, 10, e24610212563, 10.33448/rsd-v10i2.12563.

Cunha, J. L. X. L., Silva, C. A., Albuquerque, A. W., Junior, R. B. S. \& Araujo, E. (2009). Velocidade de infiltração da água em um Latossolo Amarelo submetido ao sistema de manejo plantio convencional. Revista Caatinga, 22, 199-205. http://dx.doi.org/10.30969/acsa.v7i1.131

EMBRAPA. (2017). Manual de métodos de análises de solos. 577, Embrapa.

EMBRAPA. Sistema brasileiro de classificação de solos. (2018590, Embrapa.

Fidalski, J. \& Tormena, C.A. (2007). Homogeneidade da qualidade física do solo nas entrelinhas de um pomar de laranjeira com sistemas de manejo da vegetação permanente. Revista Brasileira de Ciência do Solo, 31, 637-645. http://dx.doi.org/10.1590/S0100-06832007000400004.

Gondim, T. M. S., Wanderley, J. A. C., Souza, J. M., Feitosa Filho, J. C. \& Sousa, J. da S. (2010). Infiltração e velocidade de infiltração de água pelo método do infiltrômetro de anel em solo areno-argiloso. Revista Brasileira de Gestão Ambiental, 4, 64-73. https://doi.org/10.18378/rbga.v4i1.490

Gontijo, I., Dias Junior, M. S., Guimarães, P. T. \& Araujo Junior, C. F. (2008). Atributos físico-hídricos de um Latossolo de cerrado em diferentes posições de amostragem na lavoura cafeeira. Revista Brasileira de Ciência do Solo, 32, 2227-2234. http://dx.doi.org/10.1590/S0100-06832008000600002

Kostiakov, A. N. (1932). The dynamics of the coefficient of water percolation in soils and the necessity for studying it from a dynamic point of view for purpose of amelioration. Society of Soil Science Journal, 14, 17-2.

Libardi, P. L. (2005). Dinâmica da água no solo. 335, EDUSP.

Lima, C. L. R., Reichert, M., Reinert, D. J., Suzuki, L. E. A. S. \& Dalbianco, L. (2007). Densidade crítica ao crescimento de plantas considerando água disponível e resistência à penetração de um Argissolo Vermelho Distrófico arênico. Ciência Rural, 37, 1166-1169. http://dx.doi.org/10.1590/S010384782007000400042 .

Reid, W. V, Harold, A. et al. 2005. Ecosystem and human well-being: synthesis. 137, Island Press. Washington. 
Research, Society and Development, v. 10, n. 7, e22910713567, 2021

(CC BY 4.0) | ISSN 2525-3409 | DOI: http://dx.doi.org/10.33448/rsd-v10i7.13567

Reichardt, K. \& Timm, L. C. 2004. Solo, planta e atmosfera: conceitos, processos e aplicações. 478, Manole, São Paulo.

Reichert, J. M., Reinert, D. J. \& Braida, J. A. (2003). Qualidade dos solos e sustentabilidade de sistemas agrícolas. Ciência \& Ambiente, 14, 29-48.

Reichert, J.M., Suzuki, L.E.A.S. \& Reinert, D.J. (2007). Compactação do solo em sistemas agropecuários e florestais: identificação, efeitos, limites críticos e mitigação. In: Tópicos em ciência do solo. (Eds. Ceretta, C. A., Silva, L. S. da, Reichert, J. M.). pp. 49-134, 5, Sociedade Brasileira de Ciência do Solo, Viçosa.

Dalla Rosa J., Mafra, A. L., Nohatto, M., Ferreira, E. Z., Oliveira, O. L. P., Miquelutti, D. J., Cassol, P. C., \& Medeiros, J.C. (2009) Atributos químicos do solo e produtividade de videiras alterados pelo manejo de coberturas verdes na Serra Gaúcha. Revista Brasileira de Ciência do Solo, Viçosa, v. 33, p.179-187. http://dx.doi.org/10.1590/S0100-06832009000100019.

Santos, C. V., Levien, R., Schwarz, S. F., Mazurana, M., Petry, H. B., Zulpo, L. \& Fink, J. A. (2014). Physical-hydraulic properties of a sandy loam typic paleudalf soil under organic cultivation of 'Montenegrina' mandarin (Citrus deliciosa Tenore). Revista Brasileira de Ciência do Solo, 38, 1882-1889. http://dx.doi.org/10.1590/S0100-06832014000600023.

Santos, C. V., Levien, R., Mazurana, M., \& Zulpo, L. (2019). Alterations of chemical attributes in soils under different years of Vitis vinífera L. cultivation. Acta Brasiliensis, [S.1.], v. 3, n. 3, p. 116-123. doi: https://doi.org/10.22571/2526-4338218.

Santos, C. V. dos ., Levien, R., Mazurana, M. ., \& Zulpo, L. (2021). Organic carbon dynamics in interrows of Vitis vinifera with different years of soil use and management. Research, Society and Development, 10((3), e10610311840. DOI: 10.33448/rsd-v10i3.11840.

Silva, M. A. S. da., Mafra, Á. L., Albuquerque, J. A., Bayer, C. \& Mielniczuk, J. (2005). Atributos físicos do solo relacionados ao armazenamento de água em um Argissolo Vermelho sob diferentes sistemas de preparo. Ciência Rural, 35, 544-552. http://dx.doi.org/10.1590/S0103-84782005000300009.

Silva, N. G., Monticelli, J. M., Durayski, J. \& Calixto, C. V. (2017). Apeando do cavalo: um estudo do arranjo vitivinicultor do município de Encruzilhada Do Sul (Rs). Desenvolve - Revista de Gestão do Unilasalle, 5, 57-83.

Toigo, S. 2010. Remediação mecânica e biológica da compactação inicial de um Nitossolo Vermelho cultivado com trigo. 79 f. Dissertação (Mestrado) Programa de Pós-Graduação em Agronomia, Universidade Tecnológica Federal do Paraná, Pato Branco/PR.

Vieira, M. L., \& Klein, V. A. (2007). Propriedades físico-hídricas de um Latossolo Vermelho submetido a diferentes temas de manejo. Revista Brasileira de Ciência do Solo, 31, 1271-1280. http://dx.doi.org/10.1590/S0100-068320070006000 